\title{
Religious Tourism's Impact on City Space: Service Zones around Sanctuaries
}

\author{
Izabela Sołjan and Justyna Liro *(D) \\ Institute of Geography and Spatial Management, Jagiellonian University, 30-387 Kraków, Poland; \\ izabela.soljan@uj.edu.pl \\ * Correspondence: justyna.liro@uj.edu.pl
}

check for

updates

Citation: Sołjan, Izabela, and Justyna Liro. 2021. Religious Tourism's Impact on City Space: Service Zones around Sanctuaries. Religions 12: 165 https://doi.org/10.3390/rel12030165

Academic Editor: Kiran Shinde

Received: 1 February 2021

Accepted: 2 March 2021

Published: 4 March 2021

Publisher's Note: MDPI stays neutral with regard to jurisdictional claims in published maps and institutional affiliations.

Copyright: (c) 2021 by the authors. Licensee MDPI, Basel, Switzerland This article is an open access article distributed under the terms and conditions of the Creative Commons Attribution (CC BY) license (https:// creativecommons.org/licenses/by/ $4.0 /)$.

Abstract: Pilgrimage centers are important elements of the spatial structure of cities and simultaneously factors influencing their transformations. The pilgrimage function of sanctuaries can lead to development of service zones around them focused mainly on serving visitors, i.e., pilgrims and tourists. They often perform functions complementary to sanctuaries. Here we present the results of studies of sanctuary service zones conducted at twenty six popular Catholic sanctuaries in Europe. In this paper, we discussed the influence of the sanctuary on city space on the macro, meso and micro scales. We proposed a definition of a sanctuary service zone, and developed a model approach to the different types: initial (slightly developed) zones, dispersed zones (integrated into the urban space, with their pilgrimage function coexisting with other urban functions), and compact zones-linear, or pilgrimage districts (with dominating pilgrimage function). The development of sanctuary service zones depends mainly on the rank of the pilgrimage center, as well as on the period in which it was founded, pilgrimage traditions, and the location of the pilgrimage center in the city. This paper is a continuation and extension of research into the impact of pilgrimage centers on city space transformations in the context of socio-cultural changes in the 20th and 21st centuries.

Keywords: pilgrimage center; sanctuary; sanctuary service zones; pilgrimage; religious tourism; city space; spatial development; tourist function; sacred sites; geography of religion

\section{Introduction}

Religious tourism is one of the fastest-growing, changing sectors in the world tourism market (Reader 2014; Eade 2017; Collins-Kreiner 2019) and religious motives are still one of the common reasons for travelling around the world. As a result of socio-cultural changes in the 20th and 21st centuries-for example, mass tourism development (including religious tourism); the universality, accessibility and growing popularity of travel; the secularization, commercialization (Kaufman 2005) and globalization of societies and life (Gökariksel 2009)—changes in pilgrims' needs, motivations and behavior have occurred (Sołjan and Liro 2020; Liro 2021). Social progress has also affected the ways in which people go on pilgrimages. They demand higher-quality accommodation and other features of modern life also in pilgrimage centers (Liro et al. 2018; Sołjan and Liro 2020). Their expectations and new standards of facilities result in increasingly extensive, diverse and spatial development sanctuaries (Sołjan 2012; Sołjan and Liro 2020) and significantly influence the spatial structures of the cities where they are located. All these changes might be a response to the needs of the 'new' pilgrimage center visitors mentioned by Eade and Sallnow (1991); Badone and Roseman (2004); Collins-Kreiner (2010a, 2010b), Shinde and Rizello (2014) and (Liro 2021; Liro et al. 2017), whose motivations and expectations become diverse and have much in common with tourism in the traditional sense.

Despite this global importance and growing popularity of religious tourism, there is still a lack of knowledge about religious tourism's impact on city space. Due to the spatial-temporal influence on geographical space, religious tourism is an important research issue, especially in tourism geography, the geography of religion and urban studies 
(Deffontaines 1948; Fickeler 1947; Holloway and Vallins 2002; Shinde and Olsen 2020; Sopher 1981). Travel to sacred places was considered as a factor sacralizing space (Fickeler 1947), influencing the development of towns and settlements (Deffontaines 1948), as well as significant factors changes in the socio-geographical environment, i.e., changes in settlement networks, or cultural landscape transformations (Sopher 1981). Recently, numerous studies have pointed out the strong need to supplement research on the interaction between pilgrimages and geographical space (Collins-Kreiner 2010a, 2010b; Holloway and Vallins 2002; Rinschede and Sievers 1987) because, apart from mentioned below papers, there is no theoretical basis geographical research on the impact of the development of religious tourism on the transformation of spatial structures in cities.

Pilgrimage centers have been the subject of numerous studies, but there are very few theoretical papers about their spatial development and their influence on city space (Liro 2018; Liro and Sołjan 2016; Nolan and Nolan 1989, 1992; Rinschede 1987, 1988, 1995; Ambrosio 2007; Ambrosio and Pereira 2007; Sołjan 2011, 2012; Sołjan and Liro 2015, 2020). The network of 6150 pilgrimage centers functioning in Western Europe was described by Nolan and Nolan (1989). The sanctuary's influence on a town's development (in the macro-scale approach) and its infrastructure was described through the examples of Lourdes, Fatima, and Loreto (Rinschede 1987, 1988, 1995). Rinschede $(1987,1988,1995)$ distinguished three sanctuary development factors, on the basis of which research should be conducted: (1) spatial structure, (2) its social impact, and (3) pilgrimage movement range. Ambrosio (2007) and Ambrosio and Pereira (2007) analyzed the development of four pilgrimage centers in Europe (Banneux, Fatima, Knock and Lourdes) in comparison with the development of urban units. They highlighted the importance of place marketing, promotion and spatial development planning for the successful development of the pilgrimage center and the city itself, as well as the type of land ownership for the development of service infrastructure in the immediate vicinity of the pilgrimage center. The spatial changes were also shown in contributing papers based on examples of selected pilgrimage centers in Poland (Liro 2018; Liro and Sołjan 2016; Sołjan and Liro 2015).

The mentioned socio-cultural changes in the 20th and 21st centuries and the blurring of the boundaries between tourism and pilgrimages in many aspects have influenced pilgrimage centers (Sołjan 2012; Sołjan and Liro 2020). Today, pilgrimage centers are developed with multiple buildings (called sacred complexes or religious-recreational parks), offering additional cultural and tourist facilities for visitors. Contemporary pilgrimage centers are diverse in size, spatial organization, the number and type of buildings, as well as in the their development (Sołjan 2012; Sołjan and Liro 2020). Based on studies on pilgrimage centers, and taking into account the theoretical backgrounds to the space in sanctuaries (Rinschede 1987, 1988, 1995), a model of the contemporary pilgrimage center was developed (Soljan and Liro 2020). The model approach on the basis of empirical research assumed that the area around the sanctuary can be developed into a service zone (Figure 1). The service zone is an area of high activity for visitors, transformed by their functions (Soljan 2012; Soljan and Liro 2020). The service zone is aimed mainly at satisfying the material and tourist needs of pilgrims, influenced by the size of the pilgrimage movement.

Sanctuaries are visible in the structure of cities and are one of its many spatial elements (Soljan 2012). Religious, architectural, and other values, for example cultural ones, make sanctuaries important objects in the city space, which arouse the interest of pilgrims and tourists. They can also be a factor actively affecting urban space, influencing its changes and transformations. Owing to the existing gap in knowledge about the impact and significance of the sanctuary for the development of urban space, this article is a continuation and extension of research into spatial development and the impact of sanctuaries on city space transformations in the context of socio-cultural changes in the 20th and 21st centuries. Particular attention was paid to sanctuary service zones, the definition of which was only introduced in the previous paper (Soljan and Liro 2020). 


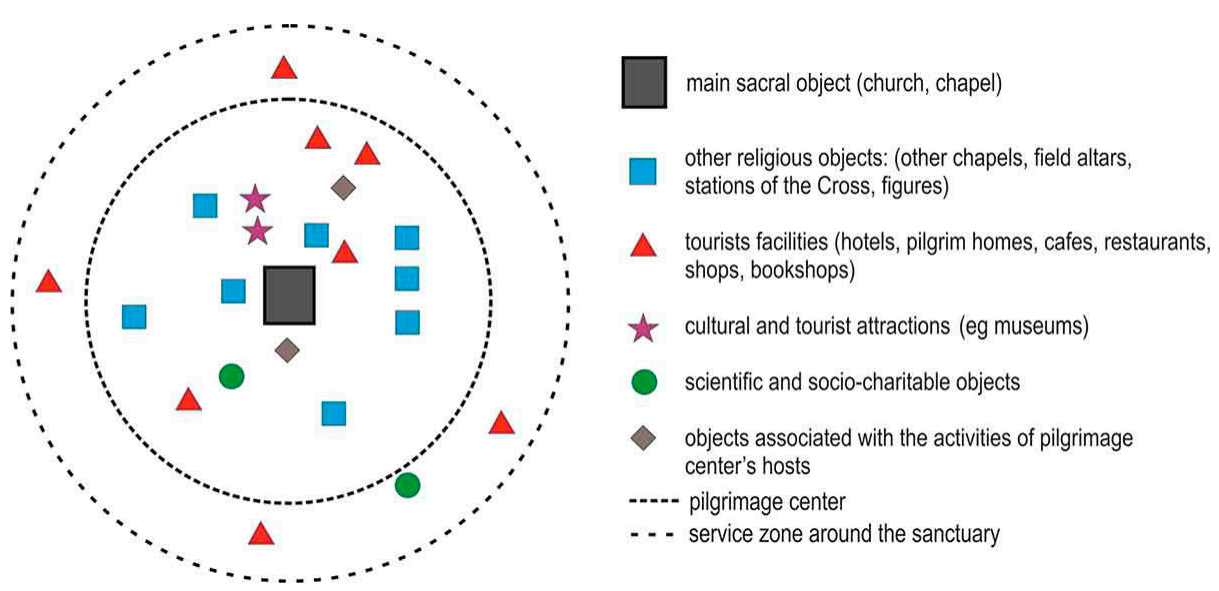

Figure 1. A model of the contemporary pilgrimage center (Figure 3; Sołjan and Liro 2020).

The aim of this paper is to present religious tourism's impact on city space based on the service zones around pilgrimage centers. Here, we present the results of studies conducted at twenty six popular Roman Catholic sanctuaries in Europe (Altötting, Assisi, Bardo, Czestochowa, Einsideln, Fatima, Kalwaria Wejherowska, Kalwaria Zebrzydowska, Kevelaer, Knock, Cracow (2), Lewocza, Loreto, Lourdes, Mariazell, Padua, Paris, Pompeii, Rome, San Giovanni Rotondo, Santiago de Compostela, Syracuse, Tuchow, and Zakopane). Particular attention was paid to the influence of sanctuaries on the urban space in the macro, meso and micro scales. We proposed a definition of a sanctuary service zone, and this paper is summarized using the model approach to sanctuary service zones types proposed here for the first time.

\section{Materials and Methods}

The materials on the impact of pilgrimage centers and the transformation of city space as well as data on the areas of visitor activity come from the field inventory carried out in the period 2008-2018, archival resources, and available studies. A valuable source of information was non-standardized interviews with the hosts of the centers. Some data were obtained from commune and municipality authorities. The research took place in the following way: in order to understand the structure of sanctuary service zones, cartographic and archival materials were analyzed. Then, a field inventory was conducted to collect current data on the areas of visitor activity and inventory of tourist infrastructure. Next, a comparative analysis of the results from the cartographic material analysis and the data obtained during the field studies was performed in order to determine religious tourism's influence on city space and develop a conceptual model of sanctuary service zones.

Field studies, inventories of objects related to the functioning of pilgrimage centers, and their location in relation to the core (main sacred object) of the sanctuary with the marking of their distance from the sanctuary service zone, and the spatial and historical analysis of the obtained data constitute the methodological basis of the presented article. The influence of pilgrimage centers on the organization of urban space has not been the subject of comprehensive geographic studies so far. In our research, we attempted to fill this gap by tracing the impact of pilgrimage centers on the organization of urban space, taking into account three spatial scales, from the immediate surroundings of the sanctuary to its impact on a scale of the entire town. The adopted criteria (described in this article) for each of the separated scales made it possible, on the basis of the conducted field inventory as well as spatial and historical analysis, to determine the impact of the sanctuary on micro, meso, and macro scales. The field studies were also aimed at separating and characterizing sanctuary service zones and showing their diversified impact on the city, from the micro scale (small zones) to the macro scale in the case of the largest pilgrimage districts. The areas closest to the sanctuary, associated with the highest number of visitors, were assumed to be sanctuary service zones. Earlier surveys on the area of the greatest activity of pilgrims, 
conducted by I. Sołjan in 2008, inter alia in Lourdes and Czestochowa, made it possible to determine the maximum range of these zones within a radius of $1000 \mathrm{~m}$ from the boundaries of the sanctuary, and so this range was adopted in this article. The main determinant of the zone was the presence of religious facilities and tourist infrastructure created to meet the needs of people visiting the pilgrimage center.

\section{Results}

\subsection{The Sanctuary in the City Space}

Sanctuaries, through their architectural form and functions, mark their presence in the urban space. They constitute a significant, symbolic space, often with great religious and cultural potential. Their impact on the city may be of a different nature and may have various effects (Figure 2). The conducted research on selected European Catholic sanctuaries has made it possible to distinguish three important spatial scales of the described phenomena (Sołjan 2012), (Figure 2):
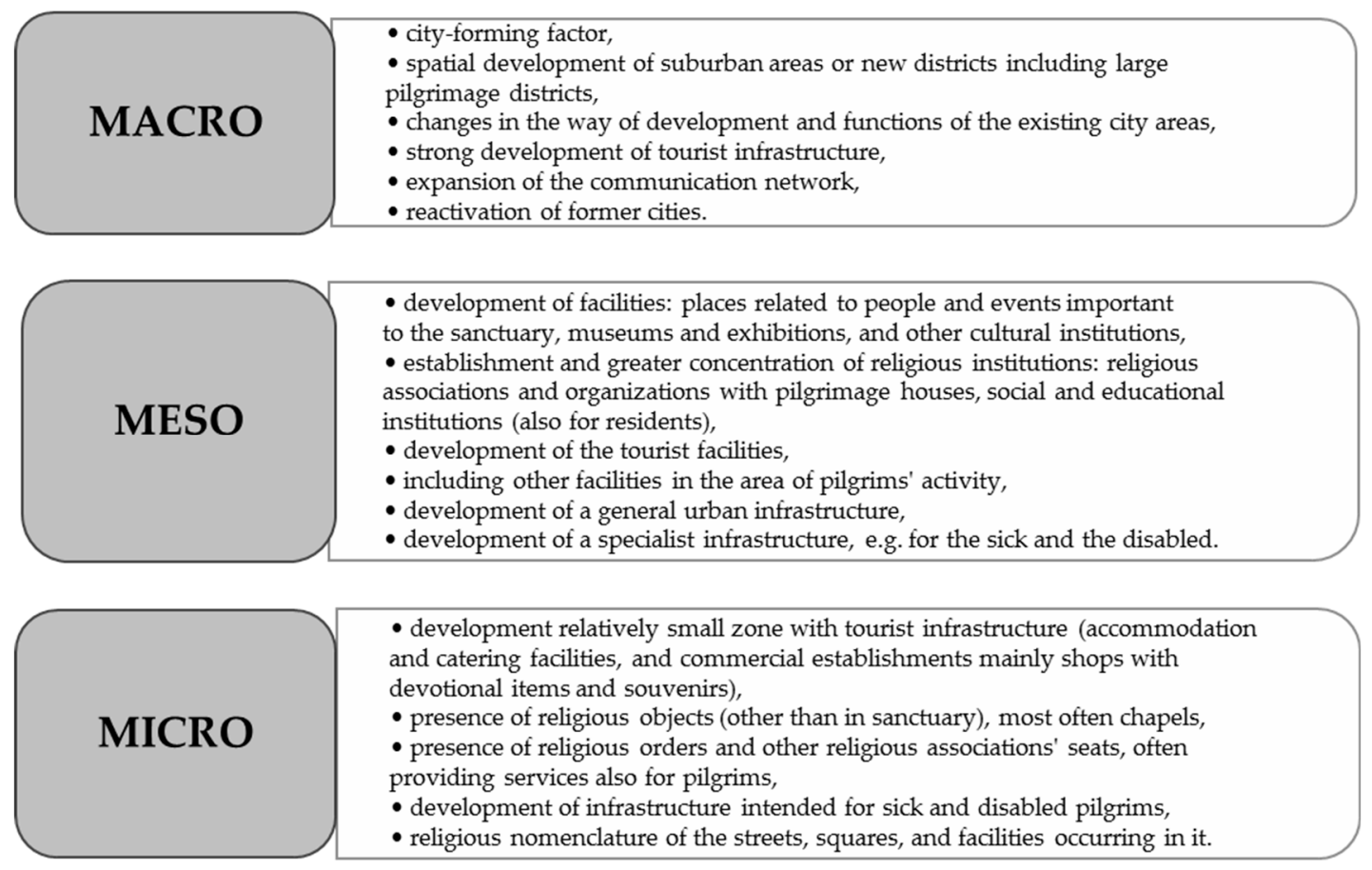

Figure 2. The spatial scales of pilgrimage centers and religious tourism's impact on the city space.

I. Changes on a macro scale: these are the greatest changes taking place in the city under the influence of the pilgrimage center, leading to fundamental changes in the urban structure and its functions.

II. Changes on a meso scale: the impact of the pilgrimage center on a meso scale is manifested in the creation of various objects, institutions, and places in the city space related thematically or functionally to it, which are located outside the sanctuary and its immediate surroundings.

III. Changes on a micro scale: the impact on a micro scale leads to changes in the urban space only in the immediate vicinity of the sanctuary. The effect of the discussed influence of the pilgrimage center is a relatively small zone with service infrastructure used by pilgrims and tourists developing around it.

\subsubsection{Macro-Scale Impact on City Space}

The greatest influence of a pilgrimage center on the organization of the space and structure of a city, defined as a macro-scale impact, takes place when there are serious spatial and functional changes in the urban structure, covering even entire settlement units 
in the case of smaller city centers, or significant parts of them (in the case of larger cities). Among these types of changes, the most important are changes:

- Resulting in the emergence of a city center;

- Leading to the spatial development of an existing city and the emergence of new districts, including large sanctuary service zones (pilgrimage district);

- In the way of development and functional changes in the already existing city areas;

- Causing the reactivation of former cities.

All these processes are generally long term, observed from a multiyear historical perspective, fundamentally changing the urban landscape. They occur mainly in the case of highly renowned (international and national) pilgrimage centers with several million people each year. They also depend on the stage of development of a given city, as well as on many social conditions, including urban policy, and sometimes even the policy of state authorities (the example of Fatima).

The city-forming function of pilgrimage centers was observed as early as in ancient times, in many now forgotten religions, such as Mesopotamia, ancient Egypt and Greece. In Western Christianity, the Middle Ages were a period favorable for the development of cities based on sanctuaries. The best example here is Santiago de Compostela, today a city with 100,000 inhabitants in Spanish Galicia, the origin of which was the tomb of St. James the Apostle discovered there at the beginning of the 9th century. Miraculous events such as this attracted the local population and aroused the interest of the church hierarchy, which resulted not only in establishing a holy place, but also in the development of settlements around it. Despite the change in social and political paradigms, the end of the Middle Ages did not stop these processes and new sanctuaries and new cities continued to emerge. Such aspirations were fostered, for example, by counter-reformation trends aimed at renewing and reviving Catholicism. In 1602, the first Calvary was founded in Poland, and the settlement which developed around the Calvary and the monastery was granted a town charter as Nowy Zebrzydow as early as in 1640. The current name of Kalwaria Zebrzydowska was not adopted until the 19th century. Additionally, in Poland, the establishment of Kalwaria Wejherowska in Pomerania was associated with the simultaneous location of the city of Wejherowo, which was granted a city charter in 1648 . In modern times, despite the basic formation of the settlement network in many European countries, it also happened that a religious center was the factor behind the foundation of a village, and then a city. Fatima is worth mentioning here, established in 'cruda radice' around the site of Our Lady's revelations in 1917. This small city has served 7-9 million pilgrims and tourists annually in recent years.

Under the influence of the pilgrimage center, a strong transformation of the spatial structure of already existing cities may also take place. The emergence of a sanctuary at a certain stage of a town's development may cause far-reaching changes in the organization of the center's space, as long as it is a dynamically developing sanctuary and its impact extends well beyond the borders of the region, or even the country. It is worth mentioning here the example of Lourdes, which was a little known town before the Marian revelations in 1858, serving as a local administrative and service center. As the result of the actions of the sanctuary, church policy, and widely publicized information about the revelations, both by the church and the media, already 50 years after the first revelations it was the most important Marian pilgrimage center in the world, visited by hundreds of thousands of pilgrims. The pilgrimage function of the city, which was also backed by the municipal authorities, caused a strong transformation of the urban structure, including the demolition of a number of houses and the construction of a new communication artery leading to the sanctuary. On previously undeveloped areas, the so-called lower town, a large pilgrimage district, the Grotto zone, was built with a strongly developed tourist infrastructure intended for visitors to the place of revelations. We observe a similar scenario of the development of San Giovanni Rotondo, a city famous for the sanctuary of St. Padre Pio, one of the most popular saints today. The expansion of the tourist infrastructure here runs in two ways, i.e., both in the historic part of the city and in the area of the pilgrimage center, where territorial 
resources make it possible to construct numerous buildings, mainly service facilities. Since the day of Padre Pio's canonization in San Giovanni Rotondo, the construction of 120 hotels has started, which shows the scale of these transformation processes (Giovine 2015).

A sanctuary may not only cause the creation of new areas in a city, but also change the development and functions of the existing districts. Highly renowned pilgrimage centers may displace other functions of the district, in which the pilgrimage function becomes the most important. This scenario generally concerns large, multifunctional cities, such as Cracow. In one of the districts of Cracow, in Podgorze, or more precisely in Łagiewniki and Borek Fałęcki, we currently have two large sanctuaries of international range, i.e., the Divine Mercy Sanctuary and the John Paul II Centre, still under development. The emergence of this sacred complex, and especially the strong development of the pilgrimage movement since the 1990s, has contributed to a change in the nature of the district, currently performing the pilgrimage function as the leading one. Following this, appropriate communication solutions are introduced, fundamentally changing the solutions in this area in the district, and thus in the city. Only commemorative plaques remind us of the old quarries and factories once present in these areas.

The city reactivation as a result of pilgrimage center is extremely rare. In this context, New Pompeii with the sanctuary of the Queen of the Holy Rosary can be mentioned. The ancient city was completely destroyed after the eruption of Mount Vesuvius in 79 AD. At the end of the 19th century, as a result of the missionary activity of Bl. Bartolo Longo, New Pompeii began to emerge from the surrounding settlements. Striving for the religious revival of the local population, he promoted the cult of Our Lady of the Rosary. Residential infrastructure and other public utility buildings developed around the church built from social donations. In 1927, New Pompeii received the status of an independent commune.

\subsubsection{Meso-Scale Impact on City Space}

The term meso-scale impact is defined as the presence in a city of places and institutions that are thematically or functionally related to the pilgrimage center, located in other parts of the city, outside the zone of direct impact of the sanctuary (Figure 2). These can be sacred buildings, places related to people and events important for the sanctuary, museums and religious exhibitions, as well as tourist facilities. Institutions functionally related to the pilgrimage center are primarily religious associations and organizations. This type of impact is not common and is more often observed in small urban centers which are large pilgrimage centers at the same time. In Fatima, approx. $2 \mathrm{~km}$ from the sanctuary, in Aljustrel — the home town of the visionaries Lucia, Francisco, and Jacinta) — a sacred and service zone complementary to the pilgrimage center was created. In addition, the monumental, so-called Great Stations of the Cross were established. In Lourdes, apart from the pilgrimage district clearly formed around the sanctuary, two large complexes serving pilgrims were established, i.e., the town of Cité Saint Pierre and the Youth Village. Cité Saint Pierre started to function in 1995 on an area of 32 ha. Six infrastructure buildings were built there, which can accommodate 500 people at a time. The Youth Village was built in 1988, in the middle of the forest, on the site of a former French Scout camp. Every year, several thousand young people from many countries of the world stay here.

The presence in the urban space of objects (or their complexes) thematically related to the sanctuary is important from the point of view of the development of the city and the pilgrimage center. It can lead to the activation of pilgrims, and thus enlarge their activity in the city. This, in turn, may increase the duration of pilgrims' stay and, taking into account the multiplier effects, it may increase the city income and the state of the economy. That is why the influence of a pilgrimage center on a meso scale is so important for smaller cities, which primarily perform the pilgrimage function. The impact on a meso scale depends not only on a sanctuary's hosts, but also on the activity of other entities, especially church and city authorities. In recent decades, owing to the development of religious tourism, many cities, including large ones, have marked out tourist routes based on religious potential and linked them to sanctuaries. In San Giovanni Rotondo, the city authorities took the initiative 
to attract pilgrims from strictly the area of the sanctuary to the historic city center. For this purpose, since the 1990s, the churches located in it began to be restored and promoted, emphasizing not only their religious and historical values, but above all their connections with St Padre Pio. In Lourdes, as part of the celebration of the 150th anniversary of the revelations, a special thematic path 'In the Footsteps of St Bernadette', and in Cracow, in order to arouse interest of those coming to the Divine Mercy Sanctuary and the John Paul II Centre in other tourist areas of the city, the route of St Faustina and the route of St John Paul II were created.

Pilgrimage centers may also affect the location of tourist facilities in parts of the city. Among the visitors to pilgrimage centers, there are also those who are looking for silence and want to spend time in concentration, away from the bustling zone filled with numerous hotels, restaurants, and shops.

Another effect of the impact of a pilgrimage center on a city on a meso scale may be a greater concentration of religious institutions, mainly religious congregations and associations. Some of the monasteries run retreat houses and provide accommodation services for pilgrims (e.g., in Fatima, Czestochowa, Cracow, Tuchow, and Zakopane). The presence of monastic facilities also favors the creation of educational institutions run by the church in the city (e.g., in Pompeii). Thus, the impact of a pilgrimage center on a city can be multifaceted, directed not only at the pilgrims arriving at the city, but also directly on its residents (thus, it is also an endogenous impact).

The presence of a pilgrimage center in a city may also lead to the development of infrastructure related to a specific group of pilgrims. In recent years, most attention-not only in pilgrimage centers-has been given to the sick and the disabled, and it results in adapting, e.g., railway stations, airports, or parking lots.

\subsubsection{Micro-Scale Impact on City Space}

Changes on a micro scale are the most common changes resulting from the existence and development of a pilgrimage center. Their effect is the development of a service zone around the sanctuary, adapted to serve pilgrims. However, this zone is relatively small, with a poorly developed tourist infrastructure, limited to a few or a dozen or so facilities (Figure 2). It is usually located in the streets or street adjacent to the pilgrimage center. We observe such a model of impact of a pilgrimage on a city in the following cases:

- In small sanctuaries, most often of regional range;

- Accumulation of tourist infrastructure within the pilgrimage center;

- As a certain transitional stage in the development of the pilgrimage center and the sanctuary service zone;

- Lack of adequate territorial facilities in the vicinity of pilgrimage center;

- Low activity of the entities administering the pilgrimage center and city, the residents.

Since the impact on a micro scale is limited mainly to the formations of sanctuary service zones, this issue will be discussed in detail in the manuscript's next sub-section.

\subsection{Sanctuary Service Zones}

The most visible manifestation of the impact of a pilgrimage center on the urban landscape is the emergence of a zone around it, serving pilgrims and tourists. It is primarily of a service and commercial nature, but can also be filled with objects of religious character. However, also in the case of the religious function of objects functioning in this zone, such as seats of religious congregations, they often provide tourist services for pilgrims, e.g., by providing accommodation. Historically, the zones in question have emerged for two main reasons:

1. Necessity to strictly separate the sacred and profane zones, justified by religious requirements;

2. Visitor needs other than spiritual or religious. 
The separation of the sacred zone from the profane zone is related to the very idea of a sacred place, i.e., one dedicated to God (a deity), where appropriate rituals and rules of behavior apply. The separation of the sacred space took place both realistically by establishing the boundaries of the sanctuary, and symbolically by the performance of cleansing rites by the people arriving. Referring to the biblical description of Jesus's anger seeing merchants in the Jerusalem temple, for centuries attempts have been made to avoid any gainful activity in their area as unworthy of such places and offensive to God. The sphere of such activities was situated outside the walls of the pilgrimage center.

On the other hand, for the pilgrimage center visitors, especially arriving from afar, and spending a longer time in the city, a natural need was to provide a place to sleep, eat, and buy souvenirs. It favored the development of tourist and commercial facilities. However, it should be noted that even in the Middle Ages, stalls with devotional items, souvenirs, or jewelry were most often put up near the temple. Pilgrims spent nights away from the pilgrimage center, often on the outskirts. This was the case, for example, in Santiago de Compostela, where in the 10th century, owing to the growing importance of the sanctuary, urbanization processes in suburban settlements began (e.g., Lucio, Pinario). At the beginning of the 12th century, along with the construction of the new cathedral, the adjacent areas began to be developed, numerous shops and currency exchange points were built and, in the previously undeveloped areas, residential houses and facilities for pilgrims were constructed. This pattern was repeated over centuries in large pilgrimage centers, with urban development providing a commercial infrastructure expanding around the sanctuary.

However, the model that has been in force for centuries has undergone fundamental changes in modern times, especially since the 1980s. Undoubtedly, these changes were based on social transformations and, with them, patterns of religious devotion and the perception of a holy place (Soljan and Liro 2020). Currently, in numerous pilgrimage centers, the presence in the strictly sacred zone of typical tourist infrastructure, with pilgrimage houses, gastronomic establishments, and commercial points, is increasingly often marked. This leads to inhibiting the development of sanctuary service zones, because their functions are taken over by pilgrimage centers. The problem is significant because in the described situation, it is not only about changing the entity generating economic profits, since it is also in sanctuary service zones that church authorities often owned many facilities, but about a paradigm shift, a qualitative change of the essence of the holy place and, in this context, the pilgrimage center. What has been forbidden and stigmatized so far for religious reasons and motives is slowly becoming a new norm. Commercialization enters pilgrimage centers increasingly from sanctuary service zones. Owing to the processes presented above, the formation of sanctuary service zones is not observed in the vicinity of many modern and dynamically developing pilgrimage centers, or their development is minimal.

Since so far in the state of knowledge, sanctuary service zones have not been defined or terminologically determined, we propose to assume that a sanctuary service zone is one that develops directly around the pilgrimage center, functionally complementary to it, developing within a radius of approx. $1000 \mathrm{~m}$ and performing primarily service functions for pilgrims and tourists.

The distinctive features of a sanctuary service zone include the presence of tourist infrastructure, which makes it possible to satisfy the needs of pilgrims. These are accommodation facilities, catering establishments, and commercial points (mainly shops with devotional items and souvenirs). Owing to the religious dimension of the pilgrimage center, sanctuary service zones are often also characterized by other features, which, however, are not necessary for their existence (Figure 2). These can include

- The presence of religious orders and seats of other religious movements and associations, often providing services also for pilgrims;

- The presence of museums and other cultural institutions, the subject matter and activities of which are related to the sanctuary;

- The presence of infrastructure intended for sick and disabled pilgrims; 
- The religious nomenclature of streets, squares, and objects occurring in it.

An important prerequisite for the efficient functioning of sanctuary service zones is also the accessibility of pilgrimage centers in terms of communication accessibility and communication solutions inside them.

The designation of sanctuary service zones was based on two criteria:

a. The morphological structure of the area, including all service facilities and other objects and institutions serving pilgrims;

b. The range of the area of pilgrim activity, the area outside the pilgrimage center. This area was designated by drawing the isochrones of pedestrian access to the sanctuary along the main communication routes leading to it. The $15 \mathrm{~min}$ isochrone of walking to the pilgrimage center was adopted as the maximum (Soljan 2012). Based on the conducted surveys and polls in the analyzed pilgrimage centers (Soljan 2012), the maximum range of sanctuary service zones was assumed at $1000 \mathrm{~m}$, and the service infrastructure for pilgrims in this area was analyzed.

The areas around pilgrimage centers can be developed in various ways and their nature can also be different. Sometimes, it is only a single object, e.g., a pilgrim's house, a shop with devotional items, or a restaurant. A noticeable regularity in sanctuary service zones is the increasing concentration of commercial services, especially shops with religious items, as they approach the pilgrimage center (Rinschede 1988, 1995). The size of the zones varies. They usually stretch along the main communication routes at a distance of 300-500 m (at most $1000 \mathrm{~m}$ ) from the borders of the pilgrimage center (Soljan 2012).

Before the characteristics of sanctuary service zones will be discussed, it is worth emphasizing that in the case of many pilgrimage centers, the above-mentioned zones are not formed at all and no changes are observed. Such a state may result from the two most common scenarios:

I. This is typical of pilgrimage centers of lesser range, where the the number of visitors throughout the year or the pilgrimage season is small and irregular. The emergence of even a small sanctuary service zone requires systematic pilgrimage movement and a relatively constant number of visitors throughout the year. The lack of a sanctuary service zone in smaller pilgrimage centers is associated with the short stay of pilgrims in them, and, certainly, has economic consequences. For many pilgrimage centers of regional range and almost all centers with a smaller range, the lack of the discussed sanctuary service zone is typical, or there is only a single facility there. In the latter case, it will be the initial sanctuary service zone.

1. Sanctuary service zones do not develop in the vicinity of large pilgrimage center complexes with a very extensive and varied infrastructure, as was discussed earlier.

Depending on the way the space around the pilgrimage center and the functions accumulating in sanctuary service zones are organized, they have the following character (Figure 3):

A. Initial—only with individual facilities for pilgrims;

B. $\quad$ Mixed (dispersed);

C. Compact, specialized only in serving pilgrims, with the following subtypes that can be distinguished here: $\mathrm{C} 1$ - compact linear zones; $\mathrm{C} 2$ - pilgrimage districts. 


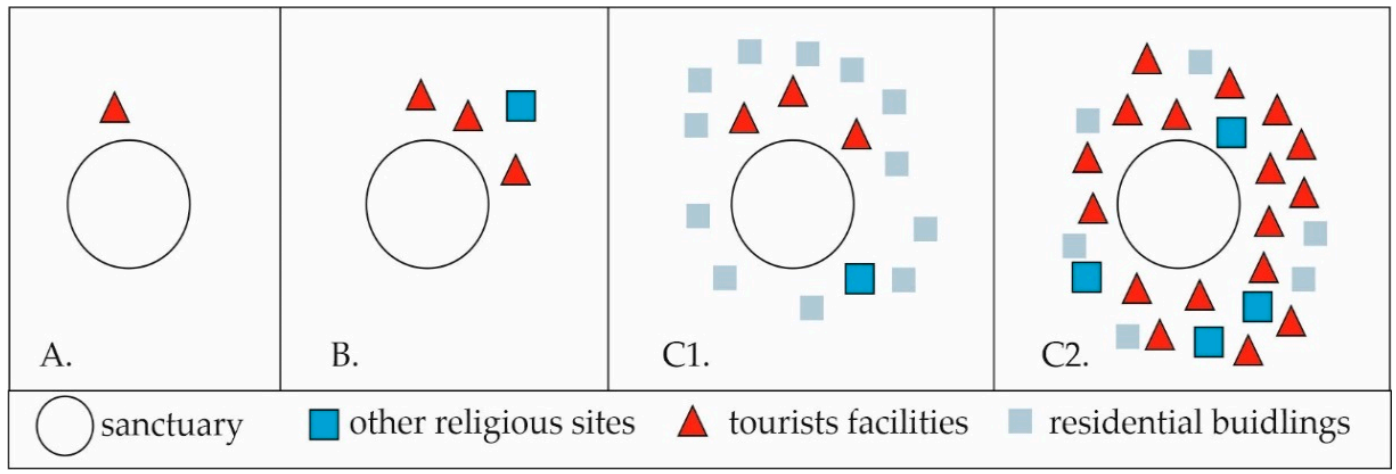

Figure 3. Types of sanctuary service zones: (A) initial; (B) mixed (dispersed); (C) compact: (C1) linear zones and (C2) districts.

In initial sanctuary service zones (Figure $3 \mathrm{~A}$ ), there is only a single service facility related to the pilgrimage center, typically with a smaller range, especially if these facilities are not present within the pilgrimage center itself.

In mixed (dispersed) zones (Figure 3B), the facilities characteristic of the zone are integrated into the urban development, and functions related to the service of pilgrims coexist with other urban functions. In the landscape of such zones, facilities serving pilgrims are intertwined with facilities for other purposes, most often residential or public buildings, e.g., municipal institutions or educational facilities. The buildings that exist here are usually of dual purpose, with their lower floors occupied by commercial premises, i.e., shops with devotional items, restaurants, and cafés, with the upper floors intended for residential purposes. The mixed sanctuary service zone is the most common zone in large pilgrimage centers. It is characteristic of cities where the pilgrimage center was or is located in the city center, and the spatial development of the city was closely related to it. The city developed around the sanctuary along with (and often much later) pilgrimage infrastructure.

Compact sanctuary service zones (Figure $3(\mathrm{C} 1, \mathrm{C} 2)$ ) are observed in the two most common cases: when they are small and cover the nearest area adjacent to the pilgrimage center, most often a street (or even a part of it) or a square, or when they occupy such a large area that they constitute a separate district. A small, compact sanctuary service zone was created, among others, in Kalwaria Zebrzydowska and in Syracuse. A similar zone exists in Cracow-Łagiewniki, which is now starting to transform into a mixed zone. Fatima and Lourdes are typical pilgrimage districts among the surveyed contemporary sanctuaries. A similar district is increasingly visible in San Giovanni Rotondo. Hotel buildings of various sizes and standards are a characteristic type of development in pilgrimage districts. The mentioned San Giovanni Rotondo (especially the part around the sanctuary) has remained a great construction site since Padre Pio's beatification in 1999 and canonization in 2002. The first hotel in Fatima was opened in 1929, and now there are over 50 of them, almost 40 of which are in the pilgrimage district (Sołjan 2012). While new hotels are still being built in San Giovanni Rotondo and Fatima, the hotel base in Lourdes has been stable in recent years, especially in the area near the pilgrimage center.

The hotel infrastructure in the zones in question is complemented by other accommodation facilities belonging mainly to church entities (to sanctuary, religious orders, or associations). Fatima is the leader in this aspect, with accommodation services provided by many monastic houses. A well-developed accommodation base can also be found in mixed zones (e.g., Czestochowa and Loreto). The church facilities are a big competition for other facilities.

Apart from the actual areas of sanctuaries, sanctuary service zones are the most significant example of the organization of urban space determined by the pilgrimage function. This is due both to the concentration of facilities and services for pilgrims, 
unprecedented in other parts of the city, and to the exceptional volume of pilgrimage movement there.

The religious nature of the zones is emphasized by the names of the streets or facilities that are typically religious or otherwise related to the sanctuary.

A noticeable change taking place today in the zones is the appearance of hotel facilities of an increasingly higher standard (e.g., in Lourdes, Fatima, San Giovanni Rotondo, and Czestochowa). At the same time, the number of uncategorized and lowest standard hotels (one- and two-star hotels) is decreasing.

All sanctuary service zones are fairly uniform in terms of the services provided for pilgrims, primarily those related to accommodation and catering. They may be supplemented by photo points, post offices, banks, and ATMs. Additionally, commercial facilities have a very narrow profile of activity. Apart from the numerous shops with devotional items with a fairly wide assortment, there are also jewelry shops with wares traditional for a given region, and bookshops. General grocery shops and chemist's shops are rare.

The infrastructure for the sick and the disabled is not sufficiently developed in all sanctuary service zones (Lourdes is an exception).

Apart from the size of the pilgrimage movement, environmental conditions are a decisive factor in the development and shape of sanctuary service zones. A pilgrimage district may develop, if there is large undeveloped space around a sanctuary, as was the case in Lourdes, Fatima, San Giovanni Rotonto, and the two analyzed sanctuaries in Cracow.

The presented zones are of a conceptual nature. In fact, there are zones with a much more complex structure and difficult-to-define boundaries. This is especially the case when the pilgrimage center itself has open borders-for example, in the case of Altötting, where there is a clear overlap between the sanctuary and the sanctuary service zone. It is worth noting that even among the international and national centers selected for the analysis, there are two, Paris and Levoča, in which a sanctuary service zone has not developed at all. An atypical sanctuary service zone may also be created when a sanctuary is located at a short distance from an object of high tourist attractiveness (in Syracuse and Cracow). This mainly applies to cities with a developed tourist function. This zone serves both pilgrims and tourists, so it partially loses the features typical of a sanctuary zone.

\section{Conclusions}

Bearing in mind the importance and popularity of religious tourism in the world and its significant impact on, among others, the transformations of geographic space and the emphasized, and still present, gap in the state of knowledge, this article discussed the influence of religious tourism on city space based on the results of research on the development of the sanctuary service zones of the largest European pilgrimage centers. The multifaceted impact of the pilgrimage center on city space can be considered at three scales: macro, meso and micro. This paper is summarized through the proposed conceptual model approach of sanctuary service zone types.

Pilgrimage centers are often a significant factor in urban space. It is enough to mention here, among numerous examples, Lourdes, Fatima, or San Giovanni Rotondo, in which the development of pilgrimage movement has led to major spatial and functional changes in the city.

From the moment of development of pilgrimages, sanctuary service zones may develop in the vicinity of pilgrimage centers, aimed mainly at satisfying tourist needs, in the space outside the sanctuary when not directly inside.

The formation of a sanctuary service zone depends on a number of factors-the most important among them is the range of a pilgrimage center. In most pilgrimage centers with local and regional pilgrimage movement, there are no sanctuary service zones, as there is no demand for tourist infrastructure services. On the other hand, sanctuary service zones are present at large international pilgrimage centers and there are many facilities aimed at satisfying the tourist and material needs of visitors. Pilgrimage traditions also 
affect the existence and development of sanctuary service zones. For the presence of tourist infrastructure to be justified, pilgrims should stay in a pilgrimage center for more than one day. Historical and socio-cultural factors are also important. Until the occurrence of the socio-cultural changes in the 20th and 21st centuries discussed in the introduction, significantly affecting pilgrimage centers and religious tourism worldwide (Soljan 2012; Soljan and Liro 2020), a sanctuary as a sacred space was reserved only for religious functions, and the pilgrims' stay for religious activities. Hence, for centuries, no facilities with non-religious functions (accommodation, catering, and trade) were located inside pilgrimage centers, which was conducive to development of sanctuary service zones. The development of sanctuary service zones is a complex process and also largely depends on other conditions. These include the cooperation of the pilgrimage center with local authorities or even the possibility of expanding and investing in new infrastructure. The development of sanctuary service zones also depends on the size of the city. Research confirmed that the greatest impact is on small- and medium-sized cities. In large cities, especially metropolises, even pilgrimage centers of international range may not cause significant changes, or they are usually limited to the district in which they are located. It is worth paying attention to the fact that, on the other hand, the development of sanctuary service zones may be weakened by investments in tourist infrastructure inside the pilgrimage center. From the second half of the 20th century and at the beginning of the 21st century, owing to socio-cultural changes (Soljan and Liro 2020), the approach to the idea of sacred space and, consequently, to the location of tourist facilities inside pilgrimage centers changed. Contemporary emerging and developing pilgrimage centers often constitute large sacred complexes in themselves, fulfilling complementary services for visitors, both religious and non-religious. Thus, investments in tourist infrastructure inside pilgrimage centers may limit the development of sanctuary service zones.

Research confirmed that most international and national pilgrimage centers develop sanctuary service zones. The most common are mixed zones, where pilgrimage services coexist with other urban functions. They developed primarily in cities where the pilgrimage center was the main cause of the establishment of a settlement unit, or development of the city followed development of pilgrimage movement and pilgrimage centers. Pilgrimage districts geared towards serving pilgrims developed around the largest pilgrimage centers and, along with the sanctuary, they are often clearly separated from other parts of the city. Linear zones, usually organized along the main street leading to the pilgrimage center, have the least impact and range. Linear zones most often develop in the vicinity of sanctuaries with smaller pilgrimage movement. It is worth noting that to an extent, the influence of the pilgrimage center on the organization of urban space around it decreases with increasing distance from it.

For the proper functioning of a pilgrimage center, it is necessary to manage tourist movement and spatial development within it, as well as in the area of its greatest impact, i.e., sanctuary service zones. Appropriate planning of these spaces may result in strengthening the positive experiences of visitors by comprehensively satisfying their travel needs, extending and diversifying visitor activity zones, extending the duration of stay (Ambrosio 2007; Ambrosio and Pereira 2007; Liro 2021; Liro et al. 2018; Sołjan and Liro 2020), as well as, in a broader sense, increasing the pilgrimage movement and furthering pilgrimage center development, taking into account the multiplier effects, ensuring better economic benefits for the sanctuary and the city (Soljan 2012). It is worth noting that marketing activities related to the management of a pilgrimage center do not have to contradict the spiritual identity of the place (Shackley 2001). On the other hand, the lack of such activities may cause unplanned and uncontrolled development of services in the sanctuary service zone, adversely affecting the perception of the pilgrimage center (Digance 2003).

Furthermore, sanctuaries also create specific public spaces in cities. Numerous pilgrimage centers are religious centers and, at the same time, places of great tourist attractiveness. In small cities, they are often the main feature attracting visitors with various motivations. The importance of a pilgrimage centers often determines the worldwide popularity and 
prestige of a city (Lourdes, Fatima, San Giovanni Rotondo, and Czestochowa), affecting the promotion and image of the city, and pilgrimage centers themselves constitute a unique potential for the development of urban space.

Author Contributions: I.S. and J.L. contributed equally to this work. All authors have read and agreed to the published version of the manuscript.

Funding: This research was funded by Institute of Geography and Spatial Management of the Jagiellonian University.

Conflicts of Interest: The authors declare no conflict of interest.

\section{References}

Ambrosio, Vitor. 2007. Marketing and development in four western European sanctuary-towns. International Journal of Management Cases 93. [CrossRef]

Ambrosio, Vitor, and Margarida Pereira. 2007. Case study 2: Christian/Catholic pilgrimage—Studies and analyses. In Religious Tourism and Pilgrimage Festivals Management: An International Perspective. Edited by Razaq Raj and Nigel D. Morpeth. Oxfordshire: CABI, pp. 140-52.

Badone, Ellen, and Sharon R. Roseman. 2004. Intersecting Journeys. The Anthropology of Pilgrimage and Tourism. London and New York: University of Illinois Press.

Collins-Kreiner, Noga. 2010a. Researching Pilgrimage. Continuity and Transformations. Annals of Tourism Research 37: 440-56. [CrossRef]

Collins-Kreiner, Noga. 2010b. The geography of pilgrimage and tourism. Transformations and implications for applied geography. Applied Geography 30: 153-64. [CrossRef]

Collins-Kreiner, Noga. 2019. Pilgrimage tourism-past, present and future rejuvenation: A perspective article. Tourism Review 75: 145-48. [CrossRef]

Deffontaines, Pierre. 1948. Géographie et religions. In Géographie Humaine 21. Paris: Gallimard.

Digance, Justine. 2003. Pilgrimage at contested site. Annals of Tourism Research 301: 143-59. [CrossRef]

Eade, John. 2017. Parish and Pilgrimage in a Changing Europe. In Migration, Transnationalism and Catholicism. Global Perspectives. Edited by Dominic Pasura and Marta Bivand Erdal. Basingstoke: Palgrave Macmillan, pp. 75-92.

Eade, John, and Michael Sallnow, eds. 1991. Contesting the Sacred. The Anthropology of Christian Pilgrimage. London and New York: Routledge.

Fickeler, Paul. 1947. Grundfragen der Religionsgeographie. Erdkunde 1: 121-44. [CrossRef]

Giovine, Michael A. 2015. When Popular Religion Becomes Elite Heritage: Tensions and Transformations at the Shrine of St. Padre Pio of Pietrelcina. In Encounters with Popular Pasts. Cultural Heritage and Popular Culture. Edited by Mike Robinson and Helaine Silverman. Cham: Springer International Publishing, pp. 31-47.

Gökariksel, Banu. 2009. Beyond the officially sacred. Religion, secularism, and the body in the production of subjectivity. Social $\mathcal{E}$ Cultural Geography 10: 657-74. [CrossRef]

Holloway, Julian, and Olivier Vallins. 2002. Placing religion and spirituality in geography. Social E Cultural Geography 3: 5-9. [CrossRef]

Kaufman, Susanne. 2005. Consuming Visions. Mass Culture and the Lourdes Shrine. Ithaca and London: Cornell University Press.

Liro, Justyna. 2018. Organizacja Przestrzeni i Funkcje Sanktuariów na Przykładzie Wybranych Ośrodków Pielgrzymkowych w Polsce [Organization of Space and Functions of Sanctuarias on the Example of Selected Pilgrimage Centres in Poland]. Ph.D. thesis, Institute of Geography and Spatial Management, Jagiellonian University, Cracow, Poland.

Liro, Justyna. 2021. Visitors' motivations and behaviours at pilgrimage centres: Push and pull perspectives. Journal of Heritage Tourism 16: 79-99. [CrossRef]

Liro, Justyna, and Izabela Sołjan. 2016. The Development of the Sacred Space and Pilgrimage Movement in the Context of Identity Formation-Example of Sanctuary of Our Lady of Lichen. In Pilgern, Wege, Heilige Orte. Seelsorge im Kontext von Menschen Unterwegs. Edited by Michaela C. Hastetter and Maciej Ostrowski. Cracow: Unum Publishing, pp. 421-27.

Liro, Justyna, Izabela Sołjan, and Elżbieta Bilska-Wodecka. 2017. Visitors' diversified motivations and behavior-The case of the pilgrimage center in Krakow Poland. Journal of Tourism and Cultural Change 15: 1-20. [CrossRef]

Liro, Justyna, Izabela Sołjan, and Elżbieta Bilska-Wodecka. 2018. Spatial Changes of Pilgrimage Centers in Pilgrimage Studies-Review and Contribution to Future Research. International Journal of Religious Tourism and Pilgrimage 6: 5-17. [CrossRef]

Nolan, Mary L., and Sidney Nolan. 1989. Christian Pilgrimage in Modern Western Europe. London: University of North Carolina Press.

Nolan, Mary L., and Sidney Nolan. 1992. Religious sites as tourism attractions in Europe. Annals of Tourism Research 191: 68-78. [CrossRef]

Reader, Ian. 2014. Pilgrimage in the Marketplace. New York and London: Routledge.

Rinschede, Gisbert. 1987. The Pilgrimage Town of Lourdes. Journal of Cultural Geography 7: 21-33. [CrossRef]

Rinschede, Gisbert. 1988. The Pilgrimage Center of Fatima/Portugal. Geographia Religionum 4: 65-98.

Rinschede, Gisbert. 1995. The pilgrimage center of Loreto, Italy. Pilgrimage Studies. Text and Context 3: 157-178. 
Rinschede, Gisbert, and Angelika Sievers. 1987. The pilgrimage phenomenon in sociogeographical research. The National Geographical Journal of India 33: 213-17.

Shackley, Myra. 2001. Managing sacred sites: Service provision and visitor experience. Material Religion the Journal of Objects Art and Belief 1: 428-29.

Shinde, Kiran, and Daniel Olsen. 2020. Religious Tourism and the Environment. CABI Religious Tourism and Pilgrimage Series. Available online: https:/ / www.cabi.org/bookshop/book/9781789241600/ (accessed on 20 January 2021).

Shinde, Kiran, and Katia Rizello. 2014. A Cross-cultural Comparison of Weekend-trips in Religious Tourism: Insights from two cultures, two countries (India and Italy). International Journal of Religious Tourism and Pilgrimage 2: 17-34. [CrossRef]

Sołjan, Izabela. 2011. Sanktuarium jako organizator przestrzeni miejskiej (na przykładzie wybranych sanktuariów w Polsce) [The sanctuary as a means of organizing urban space: A case study of selected sanctuaries in Poland]. Tourism 21: 49-58. [CrossRef]

Sołjan, Izabela. 2012. Sanktuaria i ich Rola w Organizacji Przestrzeni Miast na Przykładzie Największych Europejskich Ośrodków Katolickich [Sanctuaries and Their Role in the Organization of Urban Space on the Example of Europe's Biggest Catholic Centres]. Cracow: Institute of Geography and Spatial Management, Jagiellonian University.

Sołjan, Izabela, and Justyna Liro. 2015. Nowe centrum pielgrzymkowe w krakowskiej dzielnicy Łagiewniki-Borek Fałęcki [A new pilgrimage centre in the Cracow district of Łagiewniki-Borek Fałecki]. Peregrinus Cracoviensis 25: 135-51. [CrossRef]

Sołjan, Izabela, and Justyna Liro. 2020. The Changing Roman Catholic Pilgrimage Centers in Europe in the Context of Contemporary Socio-Cultural Changes. Social \& Cultural Geography. [CrossRef]

Sopher, David E. 1981. Geography of Religion. Englewood Cliffs: Prentice-Hall. 